\title{
Evaluasi Manajemen Mutu Internal di Fakultas Tarbiyah dan Keguruan dengan Metode Malcolm Baldrige Criteria for Education
}

\author{
Nirva Diana \\ Universitas Islam Negeri Raden Intan Lampung; email: nirvadiana @radenintan.ac.id
}

Diterima: 1 Oktober 2017. Disetujui: 12 November 2017. Dipublikasikan: Desember 2017

\begin{abstract}
This study aims to evaluate the internal quality management of each study program at the Faculty of Tarbiyah and Teacher Training of UIN Raden Intan Lampung. Place of the research is Faculty of Tarbiyah and Teacher Training of UIN Raden Intan Lampung. The type of the research used is quantitative research with Malcolm Baldrige Criteria for Education (MBCfE) method. The results of the assessment use the Baldrige criteria. The results of the research show that the performance of the Study Programs which occupy the Benchmark Leader level include: Islamic Education Management, English Education, Mathematics Education, Physics Education and Islamic Education, while the Study Programs which occupy the Industry Leader level include: Counseling Guidance, Madrasah Ibtidaiyah Teacher Training (PGMI), Raudatul Anfal Teacher Training (PGRA), Arabic Education, and Biology Education. The results of the study found that the main factors in determining the success of the study program management are leadership and human resources factors. While the factors that need to be developed in an effort to improve the quality of the study program are the factors of information management and analysis, strategic planning, and results of educational activities.
\end{abstract}

\begin{abstract}
Abstrak
Penelitian ini bertujuan untuk mengevaluasi manajemen mutu internal masing-masing program studi di Fakultas Tarbiyah dan Keguruan UIN Raden Intan Lampung. Tempat penelitian di Fakultas Tarbiyah dan Keguruan UIN Raden Intan Lampung. Jenis penelitian yang digunakan adalah penelitian kuantitatif menggunakan metode Malcolm Baldrige Criteria for Education (MBCfE). Hasil dari penilaian menggunakan kriteria Baldrige. Hasil penelitian menunjukkan bahwa kinerja program studi yang menempati level Benchmark Leader meliputi: Manajemen Pendidikan Islam, Pendidikan Bahasa Inggris, Pendidikan Matematika, Pendidikan Fisika, dan Pendidikan Agama Islam. Sedangkan Kinerja Program Studi yang menempati level Industry Leader meliputi: Bimbingan Konseling, Pendidikan Guru Madrasah Ibtidaiyah (PGMI), Pendidikan Guru Raudatul Anfal, Pendidikan Bahasa Arab, dan Pendidikan Biologi. Hasil penelitian menemukan bahwa faktor utama dalam menentukan keberhasilan pengelolaan program studi adalah faktor kepemimpinan dan sumber daya manusia. Sementara faktor yang perlu dikembangkan dalam upaya meningkatkan mutu prodi adalah faktor manajemen informasi dan analisis, perencanaan strategis, dan hasil-hasil kegiatan pendidikan.
\end{abstract}

Kata Kunci: Manajemen Mutu, $M B C f E$

() 2017 URPI, FTK UIN Raden Intan Lampung

\section{PENDAHULUAN}

Lembaga Pendidikan Tenaga Keguruan (LPTK) merupakan wadah untuk menghasilkan calon guru yang profesional (Iskandar \& Agus, 2017). Perguruan tinggi mengenal LPTK sebagai istilah lain dari program studi (prodi). Program studi pendidikan idealnya menghasilkan lulusan yang harus mampu bersaing dan menjawab tantangan zaman. Kualitas lulusan dalam hal ini calon guru yang profesional dapat dilihat diantaranya dengan mencermati proses untuk menjadi guru (Diani, 2016; Erlinda, 2017; Saregar, Diani, \& Kholid, 2017; Zulva, 2016), mulai dari pelayanan oleh tenaga 
administrasi, dosen pengajar (Saregar, 2016), kurikulum (Ahmet, 2009; Munir, 2010; Wekke \& Astuti, 2017), tempat belajar hingga wawasan mahasiswa terhadap pendidikan (Yuliani, 2017), dan sarana penunjang proses belajar mengajar di LPTK (Irwandani \& Juariyah, 2016; Irwandani, Latifah, Asyhari, Muzannur, \& Widayanti, 2017; Wahyudi, 2017; Zain, 2013). Salah satu Fakultas di UIN Raden Intan Lampung adalah Fakultas Tarbiyah dan Keguruan (FTK).

Terkait dengan tanggung jawab perguruan tinggi untuk melakukan penjaminan mutu, maka Menteri Pendidikan dan Kebudayaan (Pendidikan, 2013) mendirikan Badan Akreditasi Nasional Perguruan Tinggi (BAN-PT) untuk melakukan penjaminan mutu eksternal (Direktur Dewan Eksekutif, n.d.). Hasil akreditasi terdapat satu program studi yang terakreditasi A yaitu Program Studi Pendidikan Agama Islam. Selain itu terdapat 9 program studi yang mendapat akreditasi B yaitu Program Studi Pendidikan Bahasa Arab, Pendidikan Matematika, Pendidikan Biologi, Manajemen Pendidikan Islam, Pendidikan Fisika, Pendidikan Bahasa Inggris, Bimbingan dan Konseling, PGRA, dan PGMI.

Evaluasi internal merupakan evaluasi yang dilakukan sendiri atau dengan kata lain adalah penilaian diri (self assessment) (Freedman \& Houtz, 2004; Hasan, 2008; Ngalim, 2008; Sudjana, 2006; Vrasidas, 2000). Sebagian besar program studi di FTK UIN Raden Intan Lampung sudah melakukan evaluasi internal/ self assessment namun belum menunjukkan hasil yang maksimal. Salah satu cara untuk penilaian diri yaitu dengan menggunakan kriteria Malcolm Baldrige Criteria for Performance Excellence (MBCfPE). MBCfPE yang digunakan untuk mengukur kinerja organisasi pendidikan biasa disebut Malcolm Baldrige Criteria for Education (MBCfE). $M B C f E$ merupakan salah satu tools yang digunakan untuk mengevalusi kinerja organisasi khususnya organisasi pendidikan. Organisasi yang telah melakukan evaluasi internal menggunakan MBCfPE akan mendapatkan penghargaan Malcolm Baldrige National Award (MBNQA). Tercatat hingga tahun 2007, MBNQA telah diadopsi oleh puluhan ribu perusahaan dari 70-an negara di dunia, termasuk Indonesia. Indonesia telah mengadopsi $M B N Q A$ dengan nama Indonesia Quality Award (IQA). Penghargaan IQA pertama kali diberikan pada Badan Usaha Milik Negara (BUMN) (Direktorat Penajaminan Mutu dan Audit Internal, 2014).

Kriteria Baldrige memiliki keunggulan dibandingkan dengan sistem akreditasi lainnya, yaitu kemampuanya untuk memberikan penilaian secara menyeluruh dan terpadu yang dapat membantu pemimpin untuk berfikir visioner. Dalam Baldrige Assesment tersebut terdapat tujuh kategori penilaian yang dilakukan yaitu kepemimpinan, perencanaan strategis, fokus pelanggan dan stakeholder, informasi dan analisis, sumber daya manusia, manajemen proses, dan hasil-hasil kegiatan.

Pengukuran kualitas menggunakan Kriteria Baldrige cukup adaptif dalam lembaga pendidikan karena memungkinkan untuk melakukan penilaian mandiri (self assessment) sehingga dapat meningkatkan kecepatan proses dan kualitas Program Studi, membangun sistem kerja yang tinggi, menerjemahkan visi dan misi ke dalam strategi, dan membangun kesetiaan konsumen. Metode ini memberikan kebebasan kepada Program Studi untuk melakukan evaluasi dan pengembangan metode demi peningkatan kinerja sesuai dengan kebutuhan dan kemampuannya.

Berdasarkan uraian di atas, perlu dilakukan self assesment pada program studi di Fakultas Tarbiyah dan Keguruan UIN Raden Intan Lampung. Evaluasi ini 
dilakukan untuk mengetahui sejauh mana kualitas penyelenggaran program studi.

\section{METODE PENELITIAN}

Jenis penelitian yang digunakan adalah penelitian kuantitatif. Penelitian ini dilakukan di Fakultas Tarbiyah dan Keguruan UIN Raden Intan Lampung pada 10 (sepuluh) Program Studi, yaitu Program Studi Pendidikan Agama Islam, Pendidikan Bahasa Arab, Pendidikan Matematika, Pendidikan Biologi, Pendidikan Bahasa Inggris, Pendidikan Fisika, Manajemen Pendidikan, Bimbingan dan Konseling, PGRA, dan PGMI. Periode penilaian pada tahun ajaran 2016/2017. Teknik pengumpulan data yang digunakan adalah dengan teknik angket dan dokumentasi.

Evaluasi internal program studi (prodi) pada Fakultas Tarbiyah dan Keguruan UIN Raden Intan Lampung dengan menggunakan angket yang dilakukan untuk mencari ranking sesuai dengan kriteria Baldrige. Kuesioner ini mengukur kinerja program studi dalam bentuk persentase dengan interval 0-100\% yang mengacu pada pedoman penggunaan metode MBCfE. Teknik analisis data menggunakan metode $M B C f E$. Pengukuran data menggunakan Malcolm Baldrige untuk mengetahui kriteria program studi pada level berikut (Direktorat Penjaminan Mutu dan Audit Internal, 2014). Berikut disajikan kriteria penilaian dari Malcolm Baldrige:

Tabel 1. Kriteria Penilaian Malcolm Baldrige

\begin{tabular}{lll}
\hline Kategori & \multicolumn{1}{c}{ Skor } & \multicolumn{1}{c}{ Kriteria } \\
\hline \multirow{4}{*}{ Excellent } & $876-1000$ & World Leader \\
& $776-875$ & Benchmark Leader \\
& $676-775$ & Industry Leader \\
Average & $576-675$ & Emerging Industry Leader \\
& $476-575$ & Good Performance \\
Poor & $376-475$ & Early Improvement \\
& $276-375$ & Early Result \\
\hline
\end{tabular}

Ada 7 (tujuh) indikator yang diukur dalam penelitian ini, yaitu; kepemimpinan; (2) perencanaan strategis; (3) fokus pelanggan; (4) manajemen informasi dan analisis; (5) sumber daya manusia; (6) manajemen proses; dan (7) hasil-hasil kegiatan pendidikan.

\section{HASIL DAN PEMBAHASAN a. Prodi Pendidikan Agama Islam}

Program studi Pendidikan Agama Islam (PAI) merupakan prodi tertua di Fakultas Tarbiyah dan Keguruan UIN Raden Intan Lampung. Saat ini, Prodi PAI terakreditasi A. Berdasarkan hasil evaluasi terhadap prodi PAI diperoleh hasil sebagai berikut.

Tabel 2. Hasil Perhitungan Kriteria MBCfE Prodi Pendidikan Agama Islam

\begin{tabular}{|c|l|c|c|}
\hline No & \multicolumn{1}{|c|}{ Kriteria } & $\begin{array}{c}\text { Poin } \\
\text { Maksimal }\end{array}$ & Poin \\
\hline 1 & Kepemimpinan & 120 & 98,75 \\
\hline 2 & $\begin{array}{l}\text { Perencanaan } \\
\text { Strategis }\end{array}$ & 85 & 63,10 \\
\hline 3 & $\begin{array}{l}\text { Fokus } \\
\text { Pelanggan }\end{array}$ & 85 & 64,53 \\
\hline 4 & $\begin{array}{l}\text { Manajemen } \\
\text { Informasi dan } \\
\text { Analisis }\end{array}$ & 90 & 66,54 \\
\hline 5 & $\begin{array}{l}\text { Sumber Daya } \\
\text { Manusia }\end{array}$ & 85 & 70,64 \\
\hline 6 & $\begin{array}{l}\text { Manajemen } \\
\text { Proses }\end{array}$ & 85 & 64,05 \\
\hline 7 & $\begin{array}{l}\text { Hasil-Hasil } \\
\text { Kegiatan } \\
\text { Pendidikan }\end{array}$ & 450 & 349,00 \\
\hline \multicolumn{3}{|c|}{ Total } & Benchmark \\
\hline \multicolumn{3}{|c|}{ Kriteria Poin } \\
\hline
\end{tabular}

Tabel 2 menunjukkan bahwa Prodi PAI mempunyai beberapa keunggulan di bagian kepemimpinan ( $82 \%$ ) dan sumber daya manusia (83\%). Sementara, kriteria yang perlu diperbaiki dan ditingkatkan yaitu pada manajemen informasi dan analisis $(74 \%)$ serta perencanaan strategis (74 \%). Secara keseluruhan kualitas internal prodi Pendidikan Agama Islam berada pada kategori Excellent dengan kriteria Benchmark Leader. 


\section{b. Prodi Pendidikan Bahasa Arab}

Program studi Pendidikan Bahasa Arab (PBA) juga merupakan salah satu prodi tertua di Fakultas Tarbiyah dan Keguruan. Prodi PBA sejauh ini baru mencapai akreditasi B. Berdasarkan hasil penilaian terhadap prodi $\mathrm{PBA}$, diperoleh hasil sebagai berikut.

Tabel 3. Hasil Perhitungan Kriteria MBCfE Prodi Pendidikan Bahasa Arab

\begin{tabular}{|c|l|c|c|}
\hline No & \multicolumn{1}{|c|}{ Kriteria } & $\begin{array}{c}\text { Poin } \\
\text { Maksimal }\end{array}$ & Poin \\
\hline 1 & Kepemimpinan & 120 & 90,00 \\
\hline 2 & $\begin{array}{l}\text { Perencanaan } \\
\text { Strategis }\end{array}$ & 85 & 56,60 \\
\hline 3 & Fokus Pelanggan & 85 & 56,35 \\
\hline 4 & $\begin{array}{l}\text { Manajemen } \\
\text { Informasi dan } \\
\text { Analisis }\end{array}$ & 90 & 58,34 \\
\hline 5 & $\begin{array}{l}\text { Sumber Daya } \\
\text { Manusia }\end{array}$ & 85 & 55,17 \\
\hline 6 & $\begin{array}{l}\text { Manajemen } \\
\text { Proses }\end{array}$ & 85 & 57,87 \\
\hline 7 & $\begin{array}{l}\text { Hasil-Hasil } \\
\text { Kegiatan } \\
\text { Pendidikan }\end{array}$ & 450 & 332,50 \\
\hline \multicolumn{3}{|c|}{ Total } & 706,83 \\
\hline \multicolumn{4}{|c|}{ Kriteria Poin } \\
Leader \\
\hline
\end{tabular}

Tabel 3 menunjukkan bahwa Prodi PBA mempunyai keunggulan di bidang kepemimpinan $(75 \%)$ dan hasil-hasil kegiatan pendidikan (74 \%). Sementara, kriteria yang perlu diperbaiki dan ditingkatkan yaitu pada manajemen informasi dan analisis (65 \%) serta sumber daya manusia $(65 \%)$. Secara keseluruhan kualitas internal prodi Pendidikan Bahasa Arab berada pada kategori Excellent dengan kriteria Industry Leader.

\section{c. Prodi Manajemen Pendidikan Islam}

Program studi Manajemen Pendidikan Islam (MPI) merupakan salah satu prodi yang telah terakreditasi B. Berdasarkan hasil penilaian terhadap prodi MPI, diperoleh hasil sebagai berikut.
Tabel 4. Hasil Perhitungan Kriteria MBCfE Prodi Manajemen Pendidikan Islam

\begin{tabular}{|c|l|c|c|}
\hline No & \multicolumn{1}{|c|}{ Kriteria } & $\begin{array}{c}\text { Poin } \\
\text { Maksimal }\end{array}$ & Poin \\
\hline 1 & Kepemimpinan & 120 & 114,08 \\
\hline 2 & $\begin{array}{l}\text { Perencanaan } \\
\text { Strategis }\end{array}$ & 85 & 74,20 \\
\hline 3 & $\begin{array}{l}\text { Fokus } \\
\text { Pelanggan }\end{array}$ & 85 & 76,35 \\
\hline 4 & $\begin{array}{l}\text { Manajemen } \\
\text { Informasi dan } \\
\text { Analisis }\end{array}$ & 90 & 80,04 \\
\hline 5 & $\begin{array}{l}\text { Sumber Daya } \\
\text { Manusia }\end{array}$ & 85 & 79,27 \\
\hline 6 & $\begin{array}{l}\text { Manajemen } \\
\text { Proses }\end{array}$ & 85 & 76,95 \\
\hline 7 & $\begin{array}{l}\text { Hasil-Hasil } \\
\text { Kegiatan } \\
\text { Pendidikan }\end{array}$ & 450 & 374,89 \\
\hline \multicolumn{3}{|c|}{ Total } & 874,89 \\
\hline \multicolumn{3}{|c|}{ Kriteria Poin } \\
Leader
\end{tabular}

Tabel 4 menunjukkan bahwa Prodi MPI mempunyai keunggulan di bidang kepemimpinan $(95 \%)$ dan sumber daya manusia (93 \%). Pencapaian yang diperoleh prodi MPI sudah dalam kategori baik, dengan rata-rata di atas $85 \%$. Beberapa kriteria yang perlu diperbaiki dan ditingkatkan yaitu pada hasil-hasil kegiatan pendidikan $(83 \%)$ dan perencanaan strategis $(87 \%)$. Secara keseluruhan kualitas internal prodi Manajemen Pendidikan Islam berada pada kategori Excellent dengan kriteria Benchmark Leader. Pencapaian skor prodi MPI, yaitu 874,89 sedikit lagi akan mencapai kriteria World Leader jika upaya perbaikan terhadap kriteria-kriteria tersebut dilakukan.

\section{d. Prodi Pendidikan Bahasa Inggris}

Program studi Pendidikan Bahasa Inggris (PBI) merupakan salah satu prodi yang telah terakreditasi B. Berdasarkan hasil penilaian terhadap prodi $\mathrm{PBI}$, diperoleh hasil sebagai berikut. 
Tabel 5. Hasil Perhitungan Kriteria MBCfE Prodi Pendidikan Bahasa Inggris

\begin{tabular}{|c|l|c|c|}
\hline No & \multicolumn{1}{|c|}{ Kriteria } & $\begin{array}{c}\text { Poin } \\
\text { Maksimal }\end{array}$ & Poin \\
\hline 1 & Kepemimpinan & 120 & 108,00 \\
\hline 2 & $\begin{array}{l}\text { Perencanaan } \\
\text { Strategis }\end{array}$ & 85 & 75,50 \\
\hline 3 & $\begin{array}{l}\text { Fokus } \\
\text { Pelanggan }\end{array}$ & 85 & 72,32 \\
\hline 4 & $\begin{array}{l}\text { Manajemen } \\
\text { Informasi dan } \\
\text { Analisis }\end{array}$ & 90 & 82,61 \\
\hline 5 & $\begin{array}{l}\text { Sumber Daya } \\
\text { Manusia }\end{array}$ & 85 & 77,64 \\
\hline 6 & $\begin{array}{l}\text { Manajemen } \\
\text { Proses }\end{array}$ & 85 & 75,33 \\
\hline 7 & $\begin{array}{l}\text { Hasil-Hasil } \\
\text { Kegiatan } \\
\text { Pendidikan }\end{array}$ & 450 & 370,50 \\
\hline \multicolumn{3}{|c|}{ Total } & 861,90 \\
\hline \multicolumn{4}{|c|}{ Kriteria Poin } \\
Leader
\end{tabular}

Tabel 5 menunjukkan bahwa Prodi PBI mempunyai keunggulan di bidang manajemen informasi dan analisis (92\%) dan sumber daya manusia (91\%). Hampir sama dengan kondisi di prodi MPI, pencapaian yang diperoleh prodi PBI sudah dalam kategori baik, dengan ratarata di atas $85 \%$. Adapun beberapa kriteria yang perlu diperbaiki, yaitu pada hasil-hasil kegiatan pendidikan (82 \%) dan fokus pelanggan $(85 \%)$. Secara keseluruhan kualitas internal prodi Pendidikan Bahasa Inggris berada pada kategori Excellent dengan kriteria Benchmark Leader.

\section{e. Prodi Pendidikan Matematika}

Berdasarkan hasil penilaian terhadap Program Studi Pendidikan Matematika, diperoleh hasil sebagai berikut.

Tabel 6. Hasil Perhitungan Kriteria MBCfE Prodi Pendidikan Matematika

\begin{tabular}{|c|l|c|c|}
\hline No & \multicolumn{1}{|c|}{ Kriteria } & $\begin{array}{c}\text { Poin } \\
\text { Maksimal }\end{array}$ & Poin \\
\hline 1 & Kepemimpinan & 120 & 102,08 \\
\hline 2 & Perencanaan & 85 & 66,70 \\
\hline
\end{tabular}

\begin{tabular}{|c|c|c|c|}
\hline No & Kriteria & $\begin{array}{c}\text { Poin } \\
\text { Maksimal }\end{array}$ & Poin \\
\hline & Strategis & & \\
\hline 3 & $\begin{array}{l}\text { Fokus } \\
\text { Pelanggan }\end{array}$ & 85 & 73,12 \\
\hline 4 & $\begin{array}{l}\text { Manajemen } \\
\text { Informasi dan } \\
\text { Analisis }\end{array}$ & 90 & 76,50 \\
\hline 5 & $\begin{array}{ll}\text { Sumber Daya } \\
\text { Manusia }\end{array}$ & 85 & 71,84 \\
\hline 6 & $\begin{array}{l}\text { Manajemen } \\
\text { Proses }\end{array}$ & 85 & 67,09 \\
\hline 7 & $\begin{array}{l}\text { Hasil-Hasil } \\
\text { Kegiatan } \\
\text { Pendidikan }\end{array}$ & 450 & 372,00 \\
\hline \multicolumn{3}{|c|}{ Total } & 829,33 \\
\hline \multicolumn{3}{|c|}{ Kriteria Poin } & $\begin{array}{c}\text { Benchmark } \\
\text { Leader }\end{array}$ \\
\hline
\end{tabular}

Berdasarkan Tabel 6 diperoleh kesimpulan bahwa Prodi Pendidikan Matematika mempunyai keunggulan di kepemimpinan $(85 \%)$ dan fokus pelanggan (86 \%). Sementara kategori yang perlu dilakukan upaya perbaikan adalah pada manajemen proses (79 \%) dan perencanaan strategis $(78 \%)$. Secara keseluruhan kualitas internal prodi Pendidikan Matematika berada pada kategori Excellent dengan kriteria Benchmark Leader.

\section{f. Prodi Pendidikan Biologi}

Program Studi Pendidikan Biologi tergolong prodi baru di Fakultas Tarbiyah dan Keguruan UIN Raden Intan Lampung. Meskipun begitu, Prodi Pendidikan Biologi sudah meraih akreditasi B. Hasil evaluasi manajemen mutu internal Prodi Pendidikan Biologi disajikan dalam Tabel 7 berikut.

Tabel 7. Hasil Perhitungan Kriteria MBCfE Prodi Pendidikan Biologi

\begin{tabular}{|c|l|c|c|}
\hline No & \multicolumn{1}{|c|}{ Kriteria } & $\begin{array}{c}\text { Poin } \\
\text { Maksimal }\end{array}$ & Poin \\
\hline 1 & Kepemimpinan & 120 & 78,92 \\
\hline 2 & $\begin{array}{l}\text { Perencanaan } \\
\text { Strategis }\end{array}$ & 85 & 56,70 \\
\hline 3 & $\begin{array}{l}\text { Fokus } \\
\text { Pelanggan }\end{array}$ & 85 & 59,56 \\
\hline 4 & Manajemen & 90 & 57,73 \\
\hline
\end{tabular}




\begin{tabular}{|c|l|c|c|}
\hline No & \multicolumn{1}{|c|}{ Kriteria } & $\begin{array}{c}\text { Poin } \\
\text { Maksimal }\end{array}$ & Poin \\
\hline & $\begin{array}{l}\text { Informasi dan } \\
\text { Analisis }\end{array}$ & 85 & 60,89 \\
\hline 5 & $\begin{array}{l}\text { Sumber Daya } \\
\text { Manusia }\end{array}$ & 85 & 61,97 \\
\hline 6 & $\begin{array}{l}\text { Manajemen } \\
\text { Proses }\end{array}$ & 450 & 319,00 \\
\hline 7 & $\begin{array}{l}\text { Hasil-Hasil } \\
\text { Kegiatan } \\
\text { Pendidikan }\end{array}$ & \multicolumn{3}{|c|}{ Total } & 694,77 \\
\hline \multicolumn{3}{|c|}{ Kriteria Poin } & Industry \\
\hline \multicolumn{3}{|c|}{ Leader } \\
\hline
\end{tabular}

Berdasarkan Tabel 7 diperoleh kesimpulan bahwa Prodi Pendidikan Biologi masih memiliki banyak pekerjaan rumah yang harus diperbaiki. Beberapa diantaranya manajemen informasi dan analisis (64\%), kepemimpinan (66 \%) dan perencanaan strategis $(67 \%)$. Secara umum kualitas internal prodi Pendidikan Biologi masih berada pada kategori Excellent dengan kriteria Industry Leader.

\section{g. Prodi Pendidikan Fisika}

Program Studi Pendidikan Fisika merupakan Prodi termuda di Fakultas Tarbiyah dan Keguruan UIN Raden Intan Lampung. Prodi Pendidikan Fisika telah terakreditasi B. Hasil evaluasi manajemen mutu internal Prodi Pendidikan Fisika disajikan dalam Tabel 8 berikut.

Tabel 8. Hasil Perhitungan Kriteria MBCfE Prodi Pendidikan Fisika

\begin{tabular}{|c|l|c|c|}
\hline No & \multicolumn{1}{|c|}{ Kriteria } & $\begin{array}{c}\text { Poin } \\
\text { Maksimal }\end{array}$ & Poin \\
\hline 1 & Kepemimpinan & 120 & 108,22 \\
\hline 2 & $\begin{array}{l}\text { Perencanaan } \\
\text { Strategis }\end{array}$ & 85 & 68,10 \\
\hline 3 & $\begin{array}{l}\text { Fokus } \\
\text { Pelanggan }\end{array}$ & 85 & 68,06 \\
\hline 4 & $\begin{array}{l}\text { Manajemen } \\
\text { Informasi dan } \\
\text { Analisis }\end{array}$ & 90 & 77,73 \\
\hline 5 & $\begin{array}{l}\text { Sumber Daya } \\
\text { Manusia }\end{array}$ & 85,89 \\
\hline 6 & $\begin{array}{l}\text { Manajemen } \\
\text { Proses }\end{array}$ & $\begin{array}{l}\text { Hasil-Hasil } \\
\text { Kegiatan }\end{array}$ & 450 \\
\hline
\end{tabular}

\begin{tabular}{|c|c|c|c|}
\hline No & Kriteria & $\begin{array}{c}\text { Poin } \\
\text { Maksimal }\end{array}$ & Poin \\
\hline & Pendidikan & & \\
\hline \multicolumn{2}{|c|}{ Total } & 822,36 \\
\hline \multicolumn{2}{|c|}{ Kriteria Poin } & $\begin{array}{c}\text { Benchmark } \\
\text { Leader }\end{array}$ \\
\hline
\end{tabular}

Berdasarkan Tabel 8 diperoleh kesimpulan bahwa Prodi Pendidikan Fisika mengalami pencapaian yang cukup baik di kategori sumber daya manusia (92 $\%)$ dan kepemimpinan (90 \%). Sementara, beberapa kategori perlu untuk dilakukan peningkatan kualitasnya seperti hasil-hasil kegiatan pendidikan (78\%) dan fokus pelanggan (80 \%). Secara umum kualitas internal prodi Pendidikan Fisika berada pada kategori Excellent dengan kriteria Benchmark Leader.

\section{h. Prodi PGRA}

Hasil evaluasi manajemen mutu internal Program Studi Pendidikan Guru Raudhatul Anfal (PGRA) disajikan dalam Tabel 9 sebagai berikut.

Tabel 9. Hasil Perhitungan Kriteria MBCfE Prodi PGRA

\begin{tabular}{|c|l|c|c|}
\hline No & \multicolumn{1}{|c|}{ Kriteria } & $\begin{array}{c}\text { Poin } \\
\text { Maksimal }\end{array}$ & Poin \\
\hline 1 & Kepemimpinan & 120 & 97,67 \\
\hline 2 & $\begin{array}{l}\text { Perencanaan } \\
\text { Strategis }\end{array}$ & 85 & 65,50 \\
\hline 3 & $\begin{array}{l}\text { Fokus } \\
\text { Pelanggan }\end{array}$ & 85 & 63,59 \\
\hline 4 & $\begin{array}{l}\text { Manajemen } \\
\text { Informasi dan } \\
\text { Analisis }\end{array}$ & 90 & 66,70 \\
\hline 5 & $\begin{array}{l}\text { Sumber Daya } \\
\text { Manusia }\end{array}$ & 85 & 64,48 \\
\hline 6 & $\begin{array}{l}\text { Manajemen } \\
\text { Proses }\end{array}$ & 85 & 65,47 \\
\hline 7 & $\begin{array}{l}\text { Hasil-Hasil } \\
\text { Kegiatan } \\
\text { Pendidikan }\end{array}$ & 450 & 320,00 \\
\hline \multicolumn{3}{|c|}{ Total } & $\begin{array}{c}\text { Industry } \\
\text { Leader }\end{array}$ \\
\hline \multicolumn{3}{|c|}{ Kriteria Poin } & \\
\hline
\end{tabular}

Tabel 9 menunjukkan bahwa Prodi PGRA mempunyai keunggulan di bidang kepemimpinan $(81 \%)$ dan perencanaan 
strategis (77 \%). Adapun beberapa kategori yang perlu dilakukan peningkatan diantaranya yaitu pada hasilhasil kegiatan pendidikan $(71 \%)$ dan manajemen informasi dan analisis $(74 \%)$. Secara keseluruhan kualitas internal prodi PGRA berada pada kategori Excellent dengan kriteria Industry Leader.

\section{i. Prodi PGMI}

Berdasarkan hasil evaluasi manajemen mutu internal Program Studi Pendidikan Guru Madrasah Ibtidaiyah (PGMI) diperoleh hasil sebagai berikut.

Tabel 10. Hasil Perhitungan Kriteria MBCfE Prodi PGMI

\begin{tabular}{|c|c|c|c|}
\hline No & Kriteria & $\begin{array}{c}\text { Poin } \\
\text { Maksimal }\end{array}$ & Poin \\
\hline 1 & Kepemimpinan & 120 & 92,00 \\
\hline 2 & $\begin{array}{l}\text { Perencanaan } \\
\text { Strategis }\end{array}$ & 85 & 60,40 \\
\hline 3 & $\begin{array}{l}\text { Fokus } \\
\text { Pelanggan }\end{array}$ & 85 & 61,24 \\
\hline 4 & $\begin{array}{l}\text { Manajemen } \\
\text { Informasi dan } \\
\text { Analisis }\end{array}$ & 90 & 60,59 \\
\hline 5 & $\begin{array}{l}\text { Sumber Daya } \\
\text { Manusia }\end{array}$ & 85 & 57,70 \\
\hline 6 & $\begin{array}{l}\text { Manajemen } \\
\text { Proses }\end{array}$ & 85 & 62,49 \\
\hline 7 & $\begin{array}{l}\text { Hasil-Hasil } \\
\text { Kegiatan } \\
\text { Pendidikan }\end{array}$ & 450 & 350,00 \\
\hline \multicolumn{3}{|c|}{ Total } & 744,42 \\
\hline \multicolumn{3}{|c|}{ Kriteria Poin } & $\begin{array}{r}\text { Industry } \\
\text { Leader }\end{array}$ \\
\hline
\end{tabular}

Berdasarkan Tabel 10 diperoleh kesimpulan bahwa Prodi PGMI mempunyai keunggulan di kepemimpinan (77 \%) dan hasil-hasil kegiatan pendidikan (78 \%). Sementara kategori yang perlu dilakukan upaya perbaikan adalah pada manajemen informasi dan analisis $(67 \%)$ dan sumber daya manusia (68 \%). Secara keseluruhan prodi PGMI berada pada kategori Excellent dengan kriteria Industry Leader.

\section{j. Prodi Bimbingan Konseling}

Hasil evaluasi manajemen mutu internal Program Studi Bimbingan Konseling (BK) disajikan pada Tabel 11 berikut.

Tabel 11. Hasil Perhitungan Kriteria MBCfE Prodi BK

\begin{tabular}{|c|l|c|c|}
\hline No & \multicolumn{1}{|c|}{ Kriteria } & $\begin{array}{c}\text { Poin } \\
\text { Maksimal }\end{array}$ & Poin \\
\hline 1 & Kepemimpinan & 120 & 97,67 \\
\hline 2 & $\begin{array}{l}\text { Perencanaan } \\
\text { Strategis }\end{array}$ & 85 & 67,20 \\
\hline 3 & $\begin{array}{l}\text { Fokus } \\
\text { Pelanggan }\end{array}$ & 85 & 63,59 \\
\hline 4 & $\begin{array}{l}\text { Manajemen } \\
\text { Informasi dan } \\
\text { Analisis }\end{array}$ & 90 & 66,70 \\
\hline 5 & $\begin{array}{l}\text { Sumber Daya } \\
\text { Manusia }\end{array}$ & 85 & 64,48 \\
\hline 6 & $\begin{array}{l}\text { Manajemen } \\
\text { Proses }\end{array}$ & 85 & 65,47 \\
\hline 7 & $\begin{array}{l}\text { Hasil-Hasil } \\
\text { Kegiatan } \\
\text { Pendidikan }\end{array}$ & 450 & 345,00 \\
\hline \multicolumn{3}{|c|}{ Total } & $\begin{array}{l}\text { Industry } \\
\text { Leader }\end{array}$ \\
\hline \multicolumn{3}{|c|}{ Kriteria Poin } \\
\hline
\end{tabular}

Berdasarkan Tabel 11 diperoleh kesimpulan bahwa Prodi BK mempunyai keunggulan di kepemimpinan $(81 \%)$ dan perencanaan strategis $(79 \%)$. Sementara kategori yang perlu dilakukan upaya perbaikan adalah pada fokus pelanggan (75\%) dan manajemen informasi dan analisis $(74 \%)$. Secara keseluruhan prodi BK berada pada kategori Excellent dengan kriteria Industry Leader.

Tabel 12. Rekapitulasi Hasil Evaluasi Manajemen Mutu Prodi Fakultas Tarbiyah dan Keguruan

\begin{tabular}{|c|l|c|c|}
\hline No & Program Studi & Poin & Kriteria \\
\hline 1 & $\begin{array}{l}\text { Manajemen } \\
\text { Pendidikan Islam }\end{array}$ & 874,89 & \multicolumn{1}{|c|}{} \\
\cline { 1 - 3 } 2 & $\begin{array}{l}\text { Pendidikan Bahasa } \\
\text { Inggris }\end{array}$ & 861,90 & $\begin{array}{c}\text { Benchmark } \\
\text { Leader }\end{array}$ \\
\cline { 1 - 2 } 3 & $\begin{array}{l}\text { Pendidikan } \\
\text { Matematika }\end{array}$ & 829,33 & \multicolumn{1}{|c|}{} \\
\hline 4 & Pendidikan Fisika & 822,36 & \\
\hline 5 & Pendidikan Agama & 776,61 & \\
\hline
\end{tabular}




\begin{tabular}{|c|l|c|c|}
\hline No & Program Studi & Poin & Kriteria \\
\hline & Islam & & \\
\hline 6 & $\begin{array}{l}\text { Bimbingan } \\
\text { Konseling }\end{array}$ & 770,11 & \\
\cline { 1 - 2 } 7 & PGMI & 744,42 & \multirow{2}{*}{$\begin{array}{c}\text { Industry } \\
\text { Leader }\end{array}$} \\
\hline 8 & PGRA & 743,11 & \\
\hline 9 & PBA & 706,83 & \\
\cline { 1 - 2 } 10 & $\begin{array}{l}\text { Pendidikan } \\
\text { Biologi }\end{array}$ & 694,77 & \\
\hline
\end{tabular}

Berdasarkan Tabel 12 diperoleh kesimpulan bahwa 5 (lima) prodi di Fakultas Tarbiyah dan Keguruan yang masuk dalam kriteria Benchmark Leader dan sisanya masuk dalam Industry Leader. Namun, secara umum seluruh prodi telah masuk ke dalam kategori Excellent berdasarkan kriteria penilaian Malcolm Baldrige.

Berdasarkan hasil analisis terhadap kinerja program studi di Fakultas Tarbiyah dan Keguruan, diketahui bahwa faktor utama yang dominan dalam menentukan keberhasilan pengelolaan program studi adalah faktor Kepemimpinan $(80 \%)$ dan Sumber Daya Manusia (30 \%).

Sementara itu, faktor yang perlu dikembangkan lagi adalah Manajemen Informasi dan Analisis (60 \%), Perencanaan Strategis (40 \%), dan Hasilhasil Kegiatan Pendidikan (40 \%). Beberapa program studi seperti Pendidikan Bahasa Arab dan PGMI direkomendasikan untuk mengembangkan Sumber Daya Manusia. Sementara, Prodi Pendidikan Fisika dan Pendidikan Bahasa Inggris direkomendasikan untuk mengembangkan kerjasama dengan pengguna lulusan (Fokus Pelanggan). Program Studi Pendidikan Biologi perlu meningkatkan kinerja kepemimpinan dan melakukan perencanaan strategis guna mengejar ketertinggalannya dari program studi yang lain.

\section{SIMPULAN DAN SARAN}

Secara umum kinerja seluruh Program Studi di Fakultas Tarbiyah dan Keguruan UIN Raden Intan Lampung telah masuk ke dalam kategori Excellent berdasarkan kriteria penilaian Malcolm Baldrige. Kinerja Program Studi yang menempati level Benchmark Leader meliputi: Manajemen Pendidikan Islam, Pendidikan Bahasa Inggris, Pendidikan Matematika, Pendidikan Fisika, dan Pendidikan Agama Islam. Sementara itu, Kinerja Program Studi yang menempati level Industry Leader meliputi: Bimbingan Konseling, Pendidikan Guru Madrasah Ibtidaiyah (PGMI), Pendidikan Guru Raudatul Anfal (PGRA), Pendidikan Bahasa Arab, dan Pendidikan Biologi.

Faktor utama dalam menentukan keberhasilan pengelolaan program studi di Fakultas Tarbiyah dan Keguruan UIN Raden Intan Lampung adalah faktor Kepemimpinan dan Sumber Daya Manusia. Sementara faktor yang perlu dikembangkan dalam upaya meningkatkan mutu prodi adalah faktor Manajemen Informasi dan Analisis, Perencanaan Strategis, dan Hasil-hasil Kegiatan Pendidikan. Beberapa program studi seperti Pendidikan Bahasa Arab dan Pendidikan Biologi disarankan untuk terus memperbaiki dan meningkatkan kinerjanya.

\section{DAFTAR PUSTAKA}

Ahmet. (2009). Reform in The Social Sciences Curriculum of Turkey: An Evaluation in Terms of Teaching History. International Journal of Instruction July 2009, 2(2).

Diani, R. (2016). Pengaruh Pendekatan Saintifik Berbantukan LKS Terhadap Hasil Belajar Fisika Peserta Didik Kelas XI SMA Perintis 1 Bandar Lampung, 5(1), 83-93.

Direktorat Penajaminan Mutu dan Audit Internal. (2014). Pelatihan Kriteria Malcolm Baldrige National Quality Award (MBNQA) bagi mahasiswa jurusan Teknik Industri Universitas Surabaya.

Direktur Dewan Eksekutif. Badan 
Akreditasi Nasional Perguruan Tinggi.

Erlinda, N. (2017). Peningkatan Aktivitas dan Hasil Belajar Siswa melalui Model Kooperatif Tipe Team Game Tournament pada Mata Pelajaran Fisika di SMK. Tadris: Jurnal Keguruan Dan Ilmu Tarbiyah, 2(1), 47-52.

https://doi.org/10.24042/tadris.v2i1.1 738

Freedman, M. F., \& Houtz. (2004). A Glossary of Terms Used in Educational Asessment. Source: AGC March 2004.

Hasan, H. (2008). Evaluasi Kurikulum. Bandung: PT Remaja Rosdakrya.

Irwandani, I., \& Juariyah, S. (2016). Pengembangan Media Pembelajaran Berupa Komik Fisika Berbantuan Sosial Media Instagram sebagai Alternatif Pembelajaran. Jurnal Ilmiah Pendidikan Fisika Al-Biruni, 5(1), 33. https://doi.org/10.24042/jpifalbiruni. v5i1.103

Irwandani, Latifah, S., Asyhari, A., Muzannur, \& Widayanti. (2017). Modul digital interaktif berbasis articulate studio' 13 : pengembangan pada materi gerak melingkar kelas $\mathrm{x}$. Jurnal Ilmiah Pendidikan Fisika AlBiruni, 6(2), 221-231. https://doi.org/10.24042/jipfalbiruni. v6i2.1862

Iskandar, A., \& Agus, S. (2017). Dinamika LPTK Menuju Perguruan Tinggi Kelas Dunia (World Class University/ WCU). Perspektif Ilmu Pendidikan, 31(1), 43-54.

Munir. (2010). Kurkikulum Berbasis Teknologi Informasi dan Komunikasi. Bandung: CV Alfabeta.

Ngalim, P. (2008). Prinsip-prinsip dan Teknik Evaluasi Pengajaran. Bandung: Remaja Rosdakarya.

Pendidikan, M. (2013). Peraturan Menteri Pendidikan dan Kebudayaan Republik Indonesia. Nomor 66
Tahun 2013, 2011, 1-3.

Saregar, A. (2016). Pembelajaran Pengantar Fisika Kuantum dengan Memanfaatkan Media PhET Simulation Dan LKM Melalui Pendekatan Saintifik: Dampak Pada Minat Dan Penguasaan Konsep Mahasiswa. Jurnal Ilmiah Pendidikan Fisika Al-Biruni, 5(1), 53-60.

https://doi.org/10.24042/jpifalbiruni. v5i1.105

Saregar, A., Diani, R., \& Kholid, R. (2017). Efektivitas Penerapan Model Pembelajaran ATI (Aptitude Treatment Interaction) Dan Model Pembelajaran TAI (Team Assisted Individualy): Dampak Terhadap Hasil Belajar Fisika Siswa. Jurnal Pendidikan Fisika Dan Keilmuan, 3(1), 28-35.

Sudjana, D. (2006). Evaluasi Program Pendidikan Luar Sekolah. Bandung: PT Remaja Rosdakrya.

Vrasidas, C. (2000). Constructivism Versus Objectivism: Implications for Interaction, Course Design, and Evaluation in Distance Education. International Journal of Educational Telecommunications, 6(4), 339-346.

Wahyudi, I. (2017). Pengembangan Program Pembelajaran Fisika SMA Berbasis E-Learning dengan Schoology. Jurnal Ilmiah Pendidikan Fisika Al-BiRuNi, 6(2), 187-199. https://doi.org/10.24042/jipfalbiruni. v6i2.1850

Wekke, I. S., \& Astuti, R. W. (2017). Kurikulum 2013 di Madrasah Ibtidaiyah : Implementasi di Wilayah Minoritas Muslim. Tadris: Jurnal Keguruan Dan Ilmu Tarbiyah, 2(1), 33-39.

https://doi.org/10.24042/tadris.v2i1.1 736

Yuliani, H. (2017). Pembelajaran Fisika menggunakan Media Animasi Macromedia Flash-MX dan Gambar 
untuk Meningkatkan Pemahaman Konsep Mahasiswa. Jurnal Ilmiah Pendidikan Fisika Al-Biruni, 6(1), 13.

https://doi.org/10.24042/jpifalbiruni. v6i1.596

Zain, H. (2013). Pengembangan Pendidikan Islam Multikultural Berbasis Manajemen Sumber Daya Manusia. Tadris, 8(1), 108-124.

Zulva, R. (2016). Hubungan Antara Keterampilan Berpikir Dalam Pembelajaran Kooperatif Menggunakan Constructive Feedback. Jurnal Ilmiah Pendidikan Fisika Al-Biruni, 5(1), 61-69. https://doi.org/10.24042/jpifalbiruni. v5i1.106 